\title{
Tactile Sensation Recovery after Parotidectomy
}

\author{
Sang Youl Lee, Gyu Ho Jang, and Jeong Kyu Kim \\ Department of Otorhinolaryngology-Head and Neck Surgery, Catholic University of Daegu School of Medicine, Daegu, Korea
}

\section{이하선 절제술 후 촉각 회복 양상}

이상열 · 장규호 · 김정규

대구가톨릭대학교 의과대학 이비인후과학교실

\author{
Received February 15, 2017 \\ Revised March 20, 2017 \\ Accepted March 21, 2017 \\ Address for correspondence \\ Jeong Kyu Kim, MD, PhD \\ Department of Otorhinolaryngology- \\ Head and Neck Surgery, \\ Catholic University of Daegu \\ School of Medicine, \\ 33 Duryugongwon-ro 17-gil, \\ Nam-gu, Daegu 42472, Korea \\ Tel $+82-53-650-4525$ \\ Fax $+82-53-650-4533$
}

E-mail doctorjkkim@cu.ac.kr
Background and Objectives One of the common complications after parotidectomy is a decrease in skin sensation around the parotid gland. This is known to be associated with damage to the great auricular nerve (GAN). The purpose of this study was to investigate the pattern of tactile sensory recovery after parotidectomy and the difference in sensory recovery according to the preservation or sacrifice of the GAN.

Subjects and Method Fifty-two patients who underwent parotidectomy were enrolled in this study. The Touch Test Sensory Evaluator was used to measure the minimum tactile threshold value at 6 sites around the auricle before surgery and at 1 week, 1, 3, 6 and 12 months after surgery.

Results The tactile threshold was the highest at 1 month after parotidectomy in all 6 sites. After 1 month, the threshold value gradually decreased until 12 months after surgery. However, the threshold was not completely recovered to the preoperative threshold level. At least one branch and the main trunk of GAN were preserved in 39 patients; one of GAN branches was preserved but the main trunk of GAN was partially injured in 3 patients, and the main trunk of GAN was completely injured in 10 patients. The tactile sensory recovery showed no significant differences in relation to the GAN status.

Conclusion The tactile sensory value kept decreasing up to one month following parotidectomy and then gradually recovered. However, the tactile sensory did not recover completely even one year after surgery. The GAN preservation did not affect tactile sensory recovery. Korean J Otorhinolaryngol-Head Neck Surg 2017;60(7):347-51

Key Words Great auricular nerve $\cdot$ Parotidectomy $\cdot$ Sensory.

\section{서 론}

이하선 절제술은 주로 이하선에 생긴 종양 제거를 위해 시 행하는 술식이다. 이하선 절제술 후 발생할 수 있는 합병증으 로 출혈, 감염, 안면 신경 손상에 따른 안면 근육 마비, 장액 종(seroma) 형성, 타액 누공(salivary fistula), Frey 증후군 등 이 있으며, 흔한 합병증으로 이하선 주변의 피부 감각 저하가

This is an Open Access article distributed under the terms of the Creative Commons Attribution Non-Commercial License (http://creativecommons.org/licenses/by-nc/4.0) which permits unrestricted non-commercial use, distribution, and reproduction in any medium, provided the original work is properly cited.
있다. 피부 감각의 종류에는 약한 접촉 자극도 감지할 수 있 는 촉각, 압력을 감지하는 압각, 통증을 감지하는 통각, 높아 지는 온도의 변화를 감지하는 온각, 낮아지는 온도의 변화를 감지하는 냉각이 있다. 이하선 주변부의 피부 감각은 주로 대 이개신경(great auricular nerve)이 담당하고 있는 것으로 알 려져 있으며, ${ }^{1)}$ 이하선 절제술 중 대이개신경 손상이 발생할 수 있다. 대이개신경 손상이 피부 감각 저하와의 연관성이 크므로 보존해야 된다고 주장하는 술자도 있으며, ${ }^{2-4)}$ 장기적 추적에 따르면 대이개신경 손상과 피부 감각 저하가 큰 연관 성이 없으므로 반드시 보존할 필요가 없다고 주장하는 술자 
도 있다. ${ }^{5-7)}$ 본 연구에서는 5 가지 피부 감각 중 촉각을 측정 하는 기구를 사용하여 이하선 절제술 후 촉각 회복 양상 및 대이개신경 보존 유무에 따른 촉각 회복 차이점에 대하여 알 아보고자 하였다.

\section{대상 및 방법}

2007 2015년까지 본원에서 이하선 절제술을 시행한 179명 의 의무기록을 후향적으로 분석하였다. 이하선 절제술의 피 부 절개 방법은 변형 Blair 절개법(modified Blair incision) 으로 시행하였으며, 대이개신경의 주신경과 후방분지를 보존 하며 진행하였다. 하지만 수술 과정에서 대이개신경의 주신 경 또는 후방분지가 절단되거나 부분적 손상을 받은 환자군 이 발생하였으며, 손상을 받지 않은 군과 감각 회복 양상에 대해 비교하였다.

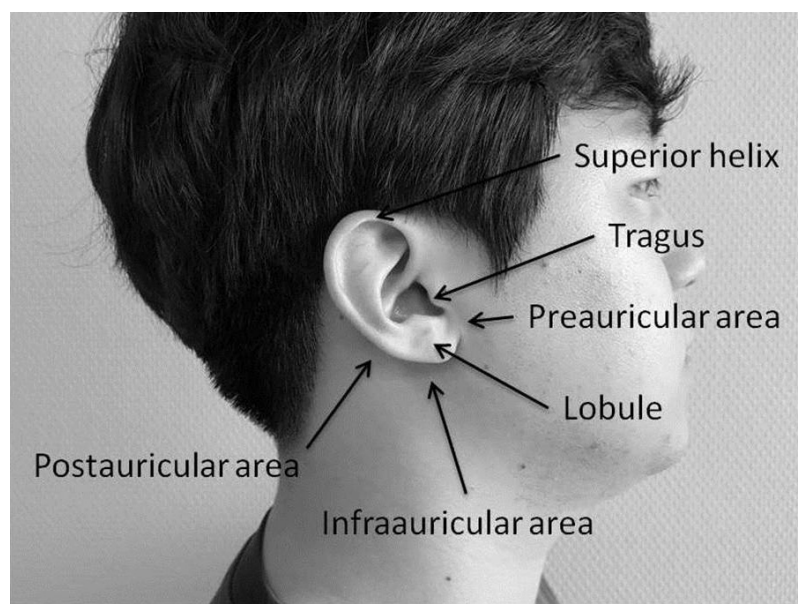

Fig. 1. Locations of touch test.

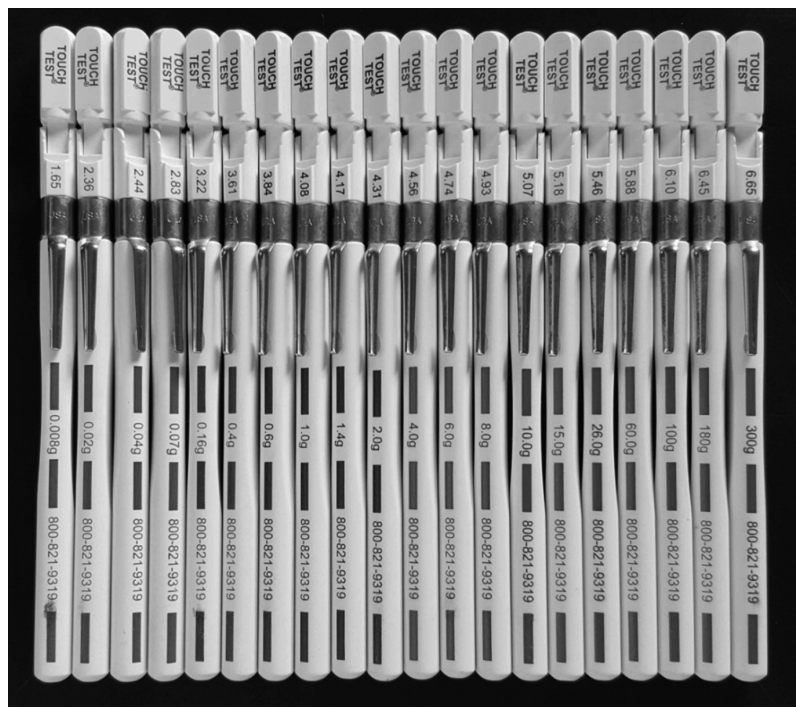

Fig. 2. Touch Test Sensory Evaluator (Touch Test Sensory Probes).
이하선 주변부의 피부 감각은 이륜 상부(superior helix), 이 수(lobule), 이주(tragus), 이개전 부위(preauricular area), 이개 하 부위(infraauricular area), 이개후 부위(postauricular area) 6군데(Fig. 1)에서 촉각 측정 도구(Touch Test Sensory Evaluator; Stoelting Co., Wood Dale, IL, USA)를 사용하여 수 술 전 및 수술 후 1 주, 1 개월, 3 개월, 6 개월, 12 개월 총 6차례 를 측정하였다. 이하선 절제 수술 후 12 개월까지 6차례의 측 정이 모두 이루어진 52명의 환자를 최종 대상으로 선정하였 고, 수술 후 12 개월까지 추적되지 않았거나, 예정된 시기에 모두 측정이 이루어지지 않은 127 명은 대상에서 제외하였다.

촉각 측정 도구(Touch Test Sensory Evaluator)는 20개의 탐침(probes)으로 최저 1.65에서 최고 6.65까지 20단계로 촉 각의 최저 역치를 측정할 수 있는 도구이다(Fig. 2). 이를 이 용하여 각 부위의 촉각 최저 역치를 측정하였는데, 최저치인 1.65 탐침을 시작으로 한 단계씩 높여가며 시행하였으며, 환 자의 피부에 탐침의 섬유가 휘어지는 정도의 힘을 주며 긁었 을 때 촉각을 최초로 느낄 수 있는 탐침의 역치값을 측정하 였다.

촉각 감소에 영향을 줄 수 있는 요인을 확인하기 위해 의무 기록을 바탕으로 대이개신경 보존 여부, 수술 종류, 조직학적 진단 등을 확인하였다. SPSS 19.0(SPSS Inc., Chicago, IL, $\mathrm{USA})$ 을 이용하여 통계 작업을 시행하였으며, 이하선 절제술

Table 1. Baseline demographics and clinical characteristics $(n=52)$

\begin{tabular}{lccc}
\hline \multicolumn{1}{c}{ Parameter } & Count & $\%$ & Median \\
\hline Age (years) & & & 49.7 \\
Sex & 21 & 40.4 & \\
$\quad$ Male & 31 & 59.6 & \\
$\quad$ Female & & & \\
Preservation of great & & & \\
auricular nerve & 39 & 75.0 \\
$\quad$ Preserved & 10 & 19.2 \\
Sacrificed & 3 & 5.8 \\
$\quad$ Partial injury & & \\
Parotidectomy type & 39 & 75.0 \\
Superficial parotidectomy & 12 & 23.1 \\
Total parotidectomy & 1 & 1.9 \\
Extracapsular dissection & & \\
Pathologic & 27 & 51.9 \\
Pleomorphic adenoma & 8 & 15.4 \\
Warthin's tumor & 3 & 5.8 \\
Basal cell adenoma & 2 & 3.8 \\
Ductal ectasia & 2 & 3.8 \\
Kimura's disease & 1 & 1.9 \\
Acinic cell carcinoma & 9 & 17.4 \\
Others* & & & \\
\hline
\end{tabular}

*lymphangioma, myoepithelioma, lipoma, chronic inflammation, etc. 
후 촉각 회복 양상은 일반화 선형 모형(generalized linear model), 대이개신경 보존 유무에 따른 촉각 차이 비교는 두 표 본 t 검정(two sample t-test) 통계 분석 방법을 이용하였다.

\section{결 과}

최종 연구 대상은 52명이었으며, 평균 나이는 49.7세, 남자 가 21 명, 여자가 31 명이었다. 대이개신경의 주 신경과 후방분 지가 보존된 환자가 39 명이었으며, 후방분지는 보존되었으나

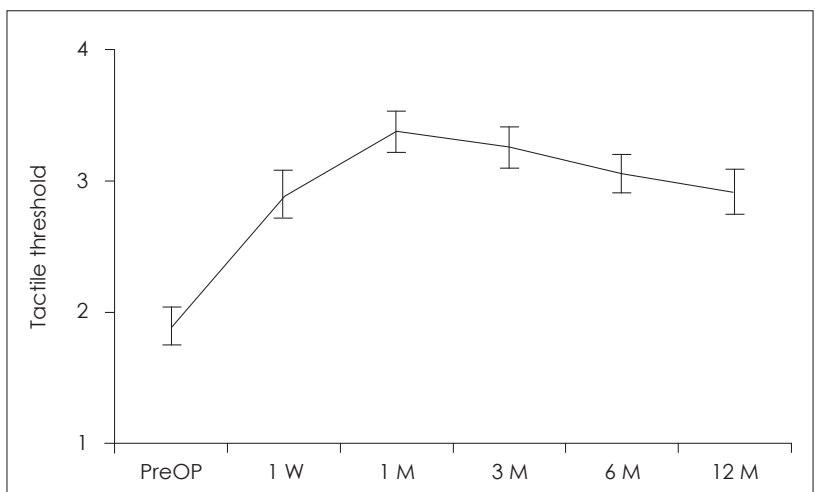

\section{A}
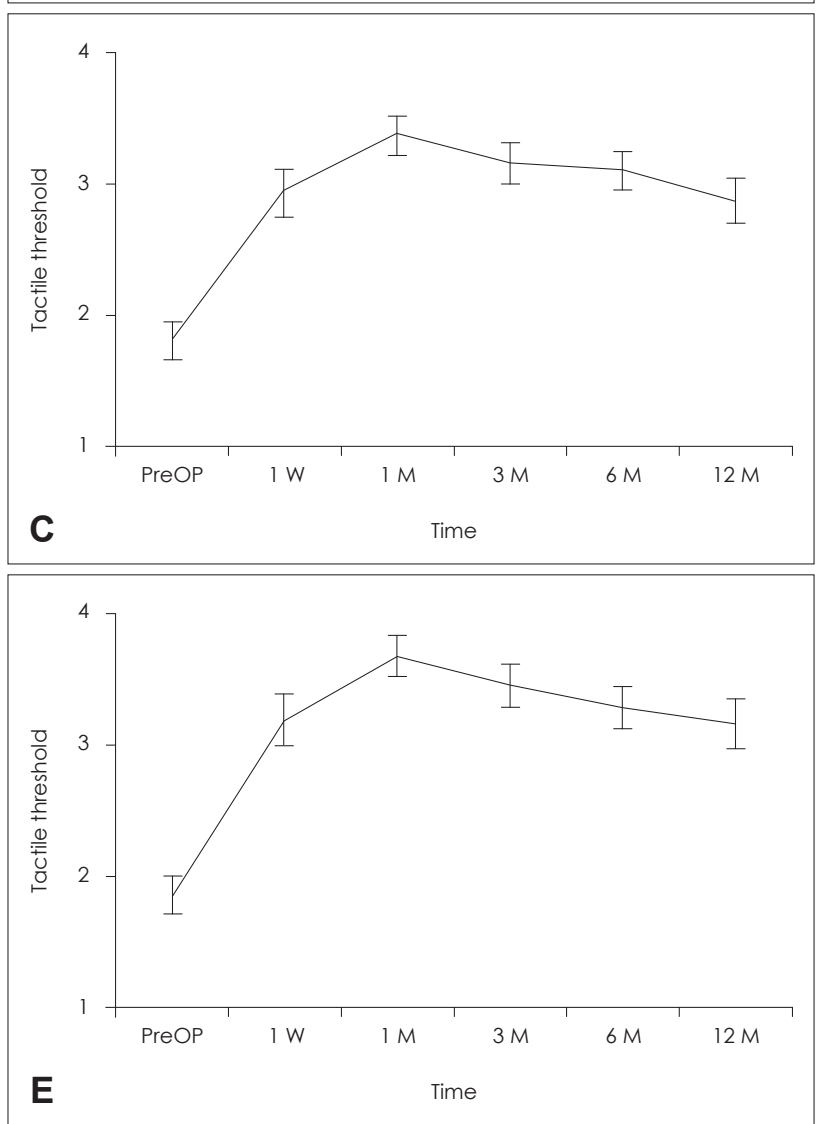

주 신경의 부분적 손상이 있었던 환자가 3명, 주 신경이 절단 된 환자가 10명이었다. 수술은 천엽절제술(superficial parotidectomy)을 시행한 경우가 39명으로 가장 많았으며, 수술 후 조직검사 결과는 다형성종(pleomorphic adenoma), 와틴 씨 종양(Warthin's tumor) 순으로 많았다(Table 1).

이하선 절제술을 시행하기 1 주일 전, 수술 후 1 주, 1 개월, 3 개월, 6개월, 12 개월 총 6차례에 걸쳐 이륜 상부(superior helix), 이수(lobule), 이주(tragus), 이개전 부위(preauricular area), 이개하 부위(infraauricular area), 이개후 부위(postauricular
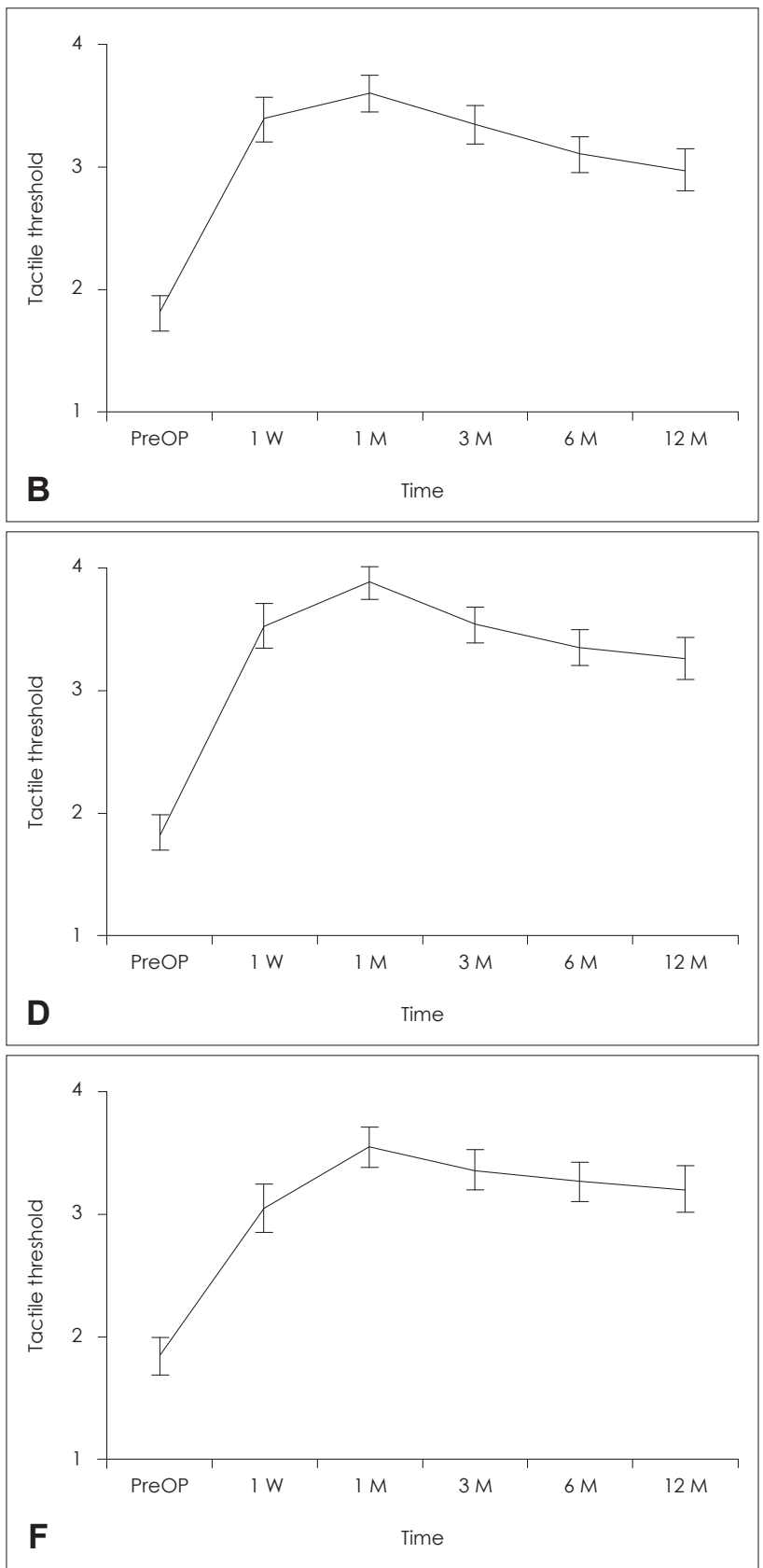

Fig. 3. Tactile sensation recovery after parotidectomy. Superior helix (A). Lobule (B). Tragus (C). Preauricular area (D). Infraauricular area $(E)$. Postauricular area $(F)$. PreOP: preoperation, W: week, M: month. 
Table 2. Difference in tactile recovery according to preservation of great auricular nerve

\begin{tabular}{|c|c|c|c|c|c|c|c|}
\hline \multirow{2}{*}{ Location } & \multicolumn{3}{|c|}{ Sacrificed } & \multicolumn{3}{|c|}{ Preserved } & \multirow{2}{*}{ p-value } \\
\hline & PreOP & 1 year & Change & PreOP & 1 year & Change & \\
\hline Superior helix & 1.95 & 2.80 & 0.86 & 1.75 & 2.97 & 1.22 & 0.103 \\
\hline Lobule & 1.77 & 2.95 & 1.18 & 1.65 & 2.99 & 1.34 & 0.168 \\
\hline Tragus & 1.81 & 2.81 & 1.00 & 1.65 & 2.91 & 1.26 & 0.146 \\
\hline Preauricular area & 1.85 & 3.22 & 1.37 & 1.65 & 3.27 & 1.62 & 0.533 \\
\hline Infraauricular area & 1.89 & 3.06 & 1.17 & 1.75 & 3.20 & 1.45 & 0.424 \\
\hline Postauricular area & 1.77 & 3.20 & 1.43 & 1.68 & 3.20 & 1.52 & 0.668 \\
\hline
\end{tabular}

PreOP: preoperation

Table 3. Measured $p$-value based on difference between the great auricular nerve sacrificed group and preserved group

\begin{tabular}{lccccc}
\hline \multicolumn{1}{c}{ Location } & 1 week & 1 month & 3 months & 6 months & 1 year \\
\hline Superior helix & 0.268 & 0.356 & 0.283 & 0.705 & 0.103 \\
Lobule & 0.122 & 0.715 & 0.198 & 0.282 & 0.168 \\
Tragus & 0.933 & 0.311 & 0.156 & 0.428 & 0.146 \\
Preauricular area & 0.599 & 0.632 & $0.035^{*}$ & 0.142 & 0.533 \\
Infraauricular area & 0.285 & 0.473 & 0.549 & 0.142 & 0.424 \\
Postauricular area & 0.137 & 0.931 & 0.841 & $0.049^{*}$ & 0.668 \\
\hline
\end{tabular}

*statistically significant $(p<0.05)$

area) 6군데에서 촉각 최저 역치를 측정하였으며, 6군데 모 두에서 수술 후 한 달째 역치가 가장 높았으며, 이후 서서히 감소하지만 수술 후 1년이 지나도 수술 전만큼 회복되지는 않는 양상을 보였다(Fig. 3).

대이개신경의 보존 유무에 따른 촉각 회복 양상의 차이가 있는가에 대해 분석하기 위해 대이개신경을 보존한 군 $(n=39)$ 과 대이개신경이 절단되거나 부분적 손상이 발생한 군( $\mathrm{n}=13)$ 으로 나누어 비교 분석하였다. 이하선 주변 6군데 모두에서 수술 1 주일 전과 수술 1 년 후의 촉각 역치값의 변화량은 대 이개신경을 보존한 군과 보존하지 못한 군 사이에 유의한 차 이를 보이지 않았다(Table 2). 동일한 방법으로 수술 후 1 주 부터 6개월까지 두 군 간의 통계적으로 유의한 차이점이 있 는지 확인하였으나, 대부분의 경우에서 유의한 차이점을 찾 을 수 없었다(Table 3).

\section{고 찰}

이하선 절제술 후 감각에는 대이개신경이 중요한 역할을 하 는 것으로 알려져 있다. 대이개신경은 경추신경 중 제 2, 3 경 추신경에서 기원하여 흉쇄유돌근을 감싸 돈 후 이하선 하연 의 뒤쪽으로 주행한다. 이하선 뒤쪽에서 전방분지와 후방분 지로 나뉘게 되고, 전방분지는 이하선 부근 얼굴의 피부 감각 을 담당하며, 후방분지는 유양돌기 및 이개, 이수의 피부 감 각을 담당한다. ${ }^{1)}$

이하선 절제 수술을 시행한 대부분의 환자에게서 수술 부
위 주변부의 감각 저하가 발생한 후 서서히 회복되는 것으로 알려져 있다. 하지만 이러한 감각 저하가 어떤 양상으로 회복 되는지 확인한 연구는 찾아보기 어렵다. Porter와 $\mathrm{Wood}^{7}$ 는 1997년에 대이개신경의 보존 유무와 상관없이 이하선 절제 술 시행 6개월 후 감각이 거의 회복된다고 보고하였다. Vieira 등은 2002 년에 이하선 절제술 후 이점식별검사를 시행하여 연구하였으며, 대이개신경을 보존한 군은 수술 6 개월 후 수 술 전과 비슷한 정도로 회복이 되었지만 대이개신경을 보존 하지 않은 군에서는 수술 12 개월 후에도 감각 저하를 보였다 고 보고하였다. 본 연구에서는 수술 후 한 달째 감각이 가장 떨어진 후 서서히 회복되나 1 년이 지나더라도 수술 전만큼의 회복은 되지 않는다는 것을 이번 연구를 통하여 확인할 수 있었다.

이하선 절제술 시 대이개신경의 보존 필요성에 대하여 의견 이 다양한 상황이다. Brown과 $\mathrm{Ord}^{2}$ 는 1989년에 대이개신경 의 보존군과 희생군으로 나누어 후향적 연구를 최초로 시행 하였으며, 대이개신경을 보존하는 군에서 대조군에 비해 감 각 저하가 유의하게 적다는 결론을 발표하였다. Yang 등은 2005년에 이하선 절제술 후 1 년 후까지도 객관적 검사상에 서 감각 저하가 발생할 수 있고, 완전 감각 소실까지 초래할 수 있으므로 대이개신경을 보존하는 것을 주장하였다. Ryan과 $\mathrm{Fee}^{3)}$ 는 2009년에 이하선 절제술 후 4 5년간 추적 관찰한 환자를 대상으로 종양 절제에 문제가 없다면 대이개신경을 보존하는 것이 바람직하다고 주장하였다.

하지만 Porter와 $\mathrm{Wood}^{7}$ 는 1997년에 대이개신경 보존군과 
희생군과의 비교 연구에서 두 군 간의 감각 저하 정도의 차이 가 없었으며, 두 군 모두에서 거의 회복되는 양상을 확인하 는 연구결과를 발표하며 대이개신경의 보존의 불필요함을 주장하였다. Patel 등 ${ }^{6}$ 은 2001년에 이하선 절제술 후 삶의 질 에 관하여 설문지를 통해 8가지 항목에 대해 연구하였으며, 대이개신경의 손상이 삶의 질에는 영향을 주지 않는다고 보 고하였다. Min 등은 은 2007년에 수술 1년 후 대이개신경 뒷가 지의 보존군과 희생군에서 감각 소실 및 삶의 질에서 유의한 차이가 없다고 보고하였다.

본 연구에서는 대이개신경을 보존한 군과 손상 받은 군에 서 촉각 회복의 양상이 통계적으로 유의한 차이를 보이지 않 았으며, 대이개신경은 이하선 절제술 시 보존하는 것이 어려운 술식은 아니나 추가적인 시간 소요 및 종양과 인접하여 주행 할 경우 대이개신경 보존으로 종양의 절제연에 손해를 줄 수 있는 점을 고려하면 반드시 보존할 필요는 없다고 생각된다.

대이개신경의 손상 후 감각이 회복되는 기전은 아직 명확 히 알려져 있지는 않지만, 피부 감각신경의 부분적 재생, 소후 두신경(lesser occipital nerve)의 보조 효과 등이 거론되었 다. ${ }^{6}$ 대이개신경을 보존하여도 감각 저하가 나타나는 것은 수 술 시 견인 등에 따른 신경의 부분적인 혈액 공급 장애에 의 한 것으로 생각된다. ${ }^{9}$

본 연구에서는 촉각 측정 도구(Touch Test Sensory Evaluator)를 사용하여 감각 역치값을 확인하였다. 이전에도 2003 년 Hui 등이이 시행한 연구 및 2009년 Ryan과 $\mathrm{Fee}^{3)}$ 가 시행한 연구에서 촉각 측정 도구(Touch Test Sensory Evaluator)가 사용된 적이 있었으며, 촉각 측정 도구(Touch Test Sensory Evaluator)를 사용하여 감각의 정도를 측정하는 것이 검사 자에 따른 차이 없이 촉각 역치를 수치화할 수 있으며, 간편 하고, 검사 시간이 짧다는 등의 장점이 있다.

본 연구의 한계점으로는 첫째, 경과 관찰을 한 기간이 1년 이었으나 기간이 더 길었다면 감각의 회복이 더 진행됨을 확
인할 수 있었을 것으로 생각되며, 둘째, 대이개신경의 손상 유무에 따른 실험군을 무작위에 의한 군으로 나누지 않았으 며 이로 인하여 보존된 군과 손상된 군의 환자 수의 차이가 컸다는 점, 셋째, 본 연구에서는 촉각 측정 도구(Touch Test Sensory Evaluator)를 사용하여 촉각 역치만을 측정하였지만 이점 분별력, 온도 감각, 통증 감각 및 삶의 질 등을 같이 측 정하였다면 더 많은 정보를 얻을 수 있었을 것으로 생각된다.

이상의 결과를 종합해 보면 이하선 절제술 후 촉각은 수술 후 한 달째 역치가 가장 높았으며, 이후 서서히 감소하지만 수 술 후 1년이 지나도 수술 전만큼 회복되지는 않는 양상을 보였 다. 대이개신경 보존 유무는 촉각 회복 양상에는 영향을 주지 않는 것으로 사료된다.

\section{REFERENCES}

1) Aboudib Júnior JH, de Castro CC. Anatomical variations analysis of the external jugular vein, great auricular nerve, and posterosuperior border of the platysma muscle. Aesthetic Plast Surg 1997;21(2):75-8.

2) Brown JS, Ord RA. Preserving the great auricular nerve in parotid surgery. Br J Oral Maxillofac Surg 1989;27(6):459-66.

3) Ryan WR, Fee WE. Long-term great auricular nerve morbidity after sacrifice during parotidectomy. Laryngoscope 2009;119(6):1140-6.

4) Yang JM, Chang JH, Hong SK, Kim BG, Park IS, Park BJ, et al. Effects of preserving the posterior branch of the greater auricular nerve at parotidectomy on postoperative peri-auricular sensation. Korean J Otolaryngol-Head Neck Surg 2005;48(8):1039-43.

5) Min HJ, Lee HS, Lee YS, Jeong JH, Cho SH, Lee SH, et al. Is it necessary to preserve the posterior branch of the great auricular nerve in parotidectomy? Otolaryngol Head Neck Surg 2007;137(4): 636-41.

6) Patel N, Har-El G, Rosenfeld R. Quality of life after great auricular nerve sacrifice during parotidectomy. Arch Otolaryngol Head Neck Surg 2001;127(7):884-8.

7) Porter MJ, Wood SJ. Preservation of the great auricular nerve during parotidectomy. Clin Otolaryngol Allied Sci 1997;22(3):251-3.

8) Vieira MB, Maia AF, Ribeiro JC. Randomized prospective study of the validity of the great auricular nerve preservation in parotidectomy. Arch Otolaryngol Head Neck Surg 2002;128(10):1191-5.

9) Hui Y, Wong DS, Wong LY, Ho WK, Wei WI. A prospective controlled double-blind trial of great auricular nerve preservation at parotidectomy. Am J Surg 2003;185(6):574-9. 